\title{
Small Business Strategies for Sustainability Beyond 10 Years
}

\author{
Gabriel E. Warren \\ Bemidji State University \\ Lynn Szostek \\ Walden University
}

\begin{abstract}
Small businesses are vital to the health of the U.S. economy, as they account for approximately $50 \%$ of all jobs and $99 \%$ of all firms. Historically, there has been a problem with small businesses being able to sustain their operations beyond 10 years. According to the U.S. Small Business Administration, when averaged across all industries, approximately $75 \%$ of new businesses failed within the first 5 years. The purpose of this multiple case study was to explore the business strategies some small business owners use to sustain their company beyond 10 years of operation. Data were gathered through semistructured interviews and a review of financial documents with a purposive sample of eight small business owners. Transcript reviews and member checking were completed to assure credibility and trustworthiness. Based on the methodological triangulation of the data sources collected, four emergent themes were identified after completing the data analysis: (a) building relationships, (b) finding your passion, (c) enhancing business knowledge, and (d) ensuring financial management. Small business leaders and their stakeholders may use the findings to advance the evolution of sustainable business models that meet the needs of small business owners.
\end{abstract}

Keywords: small business, sustainability, entrepreneurship, networking, management, business strategy

\section{Introduction}

Small businesses are essential to the health of the U.S. economy, as they account for approximately $50 \%$ of all jobs and $99 \%$ of all firms (Labedz \& Berry, 2011). Seventy-five percent of small businesses that operate in the United States fail before reaching even 5 years of operation, negatively impacting the economy (U.S. Small Business Administration, 2014). The general business problem was that some small business owners lack strategies to ensure sustainability beyond 10 years of operation. Assumptions in conducting this study included that participants provided adequate and truthful responses to the interview questions. Second, participants were representative of the population under investigation.

\section{Purpose Statement}

The purpose of this case study was to explore the business strategies some small business owners use to sustain their company beyond 10 years of operation. The focus of our study was eight small business owners with businesses having fewer than 50 employees located in Birmingham, Alabama, and Raleigh, North Carolina. This population was appropriate for this study because these small business owners have sustained their business more than 10 years and provided information-rich data regarding the phenomenon. The business ramifications of this study might be realized through 
the development of small business models that meet the needs of all stakeholders contributing to the sustainability of small businesses. Such efforts could have a direct effect on similar small businesses for contributing the on the local, state, and national economy within the United States.

\section{Research Method and Design}

The research method for this study was qualitative using a multiple case study design to gain an understanding of sustainability strategies used by eight small business owners to sustain their company beyond 10 years of operation. The use of open-ended, semistructured questions provided us with in-depth answers for exploration of the phenomenon. Cash flow statements and profit and loss statements were also collected to triangulate the data with the owners' experiences.

\section{Research Questions}

The central research question for this study was this: What are the business strategies of small business owners who have sustained their businesses beyond 10 years?

\section{Interview Questions}

The following were the open-ended interview questions that addressed the research question:

1. What characteristics must a small business owner possess to operate a sustainable business?

2. What strategies have contributed to your ability to sustain your business and become profitable for the past 10 years?

3. What do you believe is the single most important characteristic a business owner must possess to create a sustainable business?

4. What business strategies have you used to run a profitable business?

5. What else do you want to share concerning the sustainability of your small business?

\section{Definition of Terms}

Business failure: A business failure is a business having not made a net profit for the previous 2 years and may include business termination (Lussier \& Halabi, 2010).

Entrepreneurship: Entrepreneurship involves creating a new business, incorporating the assumption of risk, seeking opportunities, and developing an idea from inception to reality (Zahra \& Wright, 2011).

Sustainability: Sustainability is the ability or capacity of something to be maintained or to sustain itself (Ede et al., 2016). Sustainability in the study is referred to as establishing, growing, and maintaining the business successfully.

\section{Population and Sampling}

The study included a purposive sample of eight participants who were small business owners. The owner of the business had to be the original owner who started the business and who had worked in the same capacity since the inception. Additionally, the business must have been in operation for at 
least 10 consecutive years. The business could not have more than 50 employees. Finally, the business operated from a brick-and- mortar space and not a residential home office or virtual office space.

\section{A Review of the Professional and Academic Literature}

Successful small businesses have an effect on the economy. Small business owners employ $59 \%$ of the U.S. population (U.S. Small Business Administration, 2014) and create approximately 86\% of new jobs each year (Neumark, Wall, \& Junfu, 2011). Developing successful businesses that sustain beyond 10 years may affect communities by employing people, offering the convenience of a local product or service, contributing to the tax base, and reducing unemployment. The study involved exploring the strategies small business owners use in the first 10 years of operations that contributed to the sustainability of the business. Multiple researchers have looked at small business failure rates, and the findings have varied. One common theme agreed upon by previous scholars is that the failure rate is high and needs to be further addressed.

\section{Small Business Effects on the Economy}

The number of small businesses has increased by $49 \%$ since 1982 as a result of corporate American companies downsizing (U.S. Small Business Administration, 2014). In 2013, the estimated total number of small businesses in the United States was 23 million, which accounted for 54\% of all U.S. sales regarding the gross domestic product (U.S. Small Business Administration, 2014). As mentioned, small business also accounted for more than $86 \%$ of new jobs in the United States (Neumark et al., 2011). Small business is central to new job creation because small businesses grow faster than large corporations (Malchow-Moller, Schjerning, \& Sorensen, 2011). Small businesses are not only a key source of employment, but they also provide significant revenues to taxing bodies (local, state, federal), support local nonprofit groups, and are a source of innovation (Prasad, Tata, \& Guo, 2012).

\section{Small Business Success and Failure}

Small businesses have a significantly higher failure rate than larger corporations (Philip, 2011). According to the U.S. Small Business Administration (2014), when averaged across all industries, approximately $75 \%$ of new businesses failed within the first 5 years. Yallapragada and Bhuiyan (2011) defined small business failure in terms of (a) bankruptcy, (b) involuntary termination with a loss to creditors, (c) voluntary termination, (d) failure as an opportunity cost, (e) partnership dispute, (f) legal dispute, (g) personal limitations of owner, (h) elective discontinuance, (i) merger with or acquisition by another firm, and (j) death of the small business owner. Though more research is needed, three success factors are noted by current literature: relationship development, business expertise enhancement, and efficacious financial management.

\section{Relationship Development}

Networking is a valuable tool for business and relationship development (Cote, 2012). Networking comes in many forms ranging from informal networking with friends and family members to formal networking through community groups, religious organization, and government groups (de Klerk, \& Saayman, 2012). Understanding how to build a customer base and a value chain network is critical 
for small business success (Cote, 2012). Toson (2012) expressed the need for small business owners to develop strong networking skills as a way to increase their chances of sustainability. There is a positive correlation between strategic small business entrepreneur, external networking, and business sustainability according to Sullivan and Marvel (2011). As a business owner, there must be a strategy created for the development of networking skills and the ability to build mutually beneficial relationships.

Networking can go beyond the face-to-face encounters that small business owners conduct each day. Social media has given business owners the ability to broaden their networking footprint beyond their geographical location. Some examples of using social media to network with others include websites such as Facebook, LinkedIn, and Google+. Joining industry specific groups and writing a personal blog regarding their business can also increase the networking footprint of the small business owner (Schaupp \& Bélanger, 2014).

\section{Business Knowledge Enhancement}

Researchers agree that external support systems have positive effects on small business entrepreneurs and small business sustainability at all levels (Augusto, Eduardo, \& Jorge, 2012; Fielden \& Hunt, 2011; Patel, Fiet, \& Sohl, 2011; Soriano \& Castrogiovanni, 2012; Wang \& Shapira, 2012). Expertise, such as accounting or legal, is noted as a capability that typically does not currently exist within small business but is available elsewhere (Viljamaa, 2011). It is important for a small business owner to recognize when the complex nature of the organization extends beyond their capability, and relevant external expertise is needed (Keating, Geiger, \& McLoughlin, 2013). Chrisman, McMullan, Ring, and Holt (2012) stated that limitations exist for all business owners, despite education, knowledge, or experience; hence, the need to access external assistance when evaluating new ideas or strategies. Chrisman et al. (2012) concluded that there is a positive, curvilinear relationship between small business survival and the time spent under the guidance of an outside expert.

\section{Efficacious Financial Management}

A common characteristic among small businesses is that they lack proper funding. Kozan and Akdeniz (2014) outlined that small businesses rely heavily on personal or family resources. As a result, the business tends to be chronically in need of money. Yallapragada and Bhuiyan (2011) studied small business failure and found that when businesses fail, often it is because of the lack of adequate capital. As a result of the lack of adequate capital, the small businesses may also find it difficult to expand growth opportunities that are available in their markets (Yallapragada \& Bhuiyan, 2011).

Researchers have concluded a small business owner should create a strong financial strategy when seeking to grow and develop a sustainable business (Navis \& Glynn, 2011). If seeking outside funding, small business owners must seek ways to distinguish themselves from other businesses to persuade others to give funding (Navis \& Glynn, 2011). Common ways that small businesses raise capital include acquiring funding from methods such as bootstrapping, financial institutions, angel investors, and venture capitalist. Jones and Jayawarna (2010) described two forms of bootstrapping: raising capital without using banks or equity and gaining resources without the need for capital. 
Small business owners must employ the proper financial management procedures to maintain their business survival (Moeller \& Valentinov, 2012). Proper funding and having financial management procedures can aid in the sustainability of a small business (Kozan \& Akdeniz, 2014; Moeller \& Valentinov, 2012).

\section{Data Collection and Analysis}

Yin (2014) suggested the use of diverse types of evidence for case study research because they enable researchers to strengthen the accuracy and validity of the study. Semistructured interviews were conducted at the participants' places of business and recorded using audio recording devices. After transcribing the interviews into a Word document, the transcriptions were shared with the participants for verification. We then made the any necessary revisions before initiating coding and sorting of data. We used the NVivo 10 software program to assist with coding and sorting data into themes for analysis facilitating our organizing the data for coding, data linking, content analysis, and findings confirmation. Once the data were initially analyzed, this preliminary analysis was shared with participants as a means of member checking. We then made the necessary revisions before continuing with the analysis.

Because we had professional relationships with a few of the small business owners, emphasis on triangulation assisted in reducing the potential for bias. Therefore, the use of methodological triangulation improved our understanding of the complex nature of the phenomenon while enabling us to explore the subjective experiences of the small business owners objectively. Data from interviews were triangulated with the findings from financial documents. We then compared the results of our data analysis to the literature.

\section{Ethical Research}

There was minimal risk from participating in this study with the probability and degree of risk not greater than those ordinarily encountered in daily life. All individuals for this study volunteered for participation without coercion and signed an easily understandable informed consent form. While a few of the participants were business acquaintances, there was no conflict of interest, and there was no change in the relationship status because of participation or nonparticipation in the study. Accordingly, participants had the ability to withdraw from the study at any time by contacting us via phone or e-mail. There were no incentives offered for participation in this study. To maintain confidentiality, a coding system for data identified participants for data analysis without reference to the participant's business, through a numbering system. Each participant received an identifying label, such as Participant 1 or Participant 2.

Storage of all data including audio recordings, interview notes, and transcriptions was via an encrypted computer file or locked file cabinet for 5 years, to protect the rights and identities of the participants. All financial documents were viewed on the business' sites, and never removed. After 5 years, the destruction of the data will ensure the confidentiality of all participants.

\section{Reliability and Validity}

\section{Reliability}

In qualitative research, achieving reliability equates with the ability to duplicate the components of the study, the consistency of data collection, and accuracy of the data recording processes. Given this, 
a consistent process was followed by both researchers using the same semistructured questions. We conducted transcript reviews and member checking with participants for accuracy, ensured proper coding, and validated our interpretations.

\section{Validity}

Tracy (2010) suggested achieving credibility in qualitative studies includes a rich description and detailing of the personal experiences garnered from in-depth interviews with study participants. We used verbatim transcription of participant interviews and member checking to establish validity ensuring an accurate description of the participants' experiences. We identified themes through triangulating data from participant interviews and documentary evidence assuring the validity of the study findings. In addition, the participant interviews continued to demonstrate data saturation to ensure no new or relevant information emerged.

\section{Results and Data Analysis Principal Findings and Themes}

The purpose of this qualitative case study was to identify and explore the strategies small business owners used to sustain their businesses beyond 10 years. Based on the methodological triangulation of the data sources collected, four emergent themes were identified after completing the data analysis: (a) building relationships, (b) finding your passion, (c) enhancing business knowledge, and (d) ensuring financial management.

\section{Theme 1: Building Relationships}

The first theme revealed from the data collection was the need for the small business owner to build strong relationships. Participant 2 stated, "You cannot overvalue relationships." Participant 2 summed up the value of building relationships in his response: "The crux of everything in business falls on knowing how to build the right relationships." Participant 3 revealed that relationship building skills are essential to the sustainability of small business: "Building relationships with customers is important, and building internal relationships with employees is essential." All participants mentioned the importance of building relationships in the sustainability of their business. Participant 4 offered, "Without networking and building a positive relationship with our community, we would have closed our doors years ago."

Participant 7 continued that "relationships are the cornerstone to any small business success." Establishing trust with customers, suppliers, vendors, employees, and other industry professionals is one key component of building a sustainable small business (de Klerk \& Saayman, 2012). The overall statements made by participants align well with the research of de Klerk and Saayman. The authors mentioned that no relationship can be ignored and that all have to be cultivated in order for businesses to be successful.

Participants 4-8 also mentioned that the means to networking has taken an enhanced view with the presence of social media. They noted that community based relationships are key, but using social media enables them to enhance business knowledge, vendor outreach, alternative funding sources, and general support on a global scale. "Though this global reach is inspiring and free, therefore cost effective, it cannot replace the power of handshake relationships at the local level," offered Participant 8. Participants 4-8 continued with a discussion about balance local and global relationships as the best of all worlds. 


\section{Alignment With Literature}

The emergent theme of building relationships aligns with what previous researchers have identified as a part of findings. Beyond the aforementioned work of deKlerk and Saayman, previous researchers noted that building external relationships can have a positive effect on the sustainability of the small business (Anderson \& Ullah, 2014, Augusto et al., 2012; Keating et al., 2013).

Several participants' (Participants 2, 4, 6, 7, and 8) mentioned that external collaborative partnerships have contributed to expansion of services, recruitment of talent, increase of customers, and access to alternative funding. Yet, each participant in this study also mentioned the importance of being able to establish and maintain positive employee relationships to effect and sustain high performance and customer service.

\section{Theme 2: Finding Your Passion}

The second theme was finding what your passion is in business. Participants 1 and 2 mentioned the need to own a business in the industry you love as key to running a sustainable business. Participant 1 noted, "You have to have a passion and a dream for what you do." Participant 3 responded, "find something that you enjoy doing, because the business takes a major part of your life away." Participants 4, 5, 6, 7, and 8 echoed this statement. They also offered that "your passion will become contagious to others involved in your business. So your dedication, commitment, and energy are vital to your business success." "You are 'on' 24/7," Participant 8 mentioned. The results from our study indicate that if a person wants to start and sustain a small business, they need to have a passion for the industry to increase the likelihood of the business surviving beyond 10 years.

\section{Alignment With Literature}

Existing literature supported the importance of being passionate about the industry that you choose to start a business. Tasnim, Yahya, and Zainuddin, (2014) stated that the more passionate a person is about their passion, the more sentimental they will be about achieving their business goals. Being sentimental aids in motivating business owners to work longer hours, push harder towards reaching sales goals, and developing the soft skills needed to operate a sustainable business (Tasnim et al., 2014). Degeorge and Fayolle (2011) stated that business owners are more passionate about their work and are willing to work longer hours when they feel they have autonomy of choice and decisional freedom. Participant 3 confirmed Degeorge and Fayolle's statement when by stating, "when a person finds their passion, work is no longer work, it becomes fun."

\section{Theme 3: Enhancing Business Knowledge}

Some factors that could contribute to small business failures are inadequate planning, lack of strategy, and poor implementation (Phillip, 2011). Risk management and poor decision-making by management are key factors that can lead to increased business failures (Phillip, 2011). These concepts were echoed by various participants. Participant 8 stated, "Any business owner thinking they can do and know it all, will not be around next year." The same participant furthered that he uses outside expertise as need, particularly in the areas of accounting, tax preparation, payroll, general human resources, and legal matters. Participant 5 offered, "I have a huge complement of expertise. They are all part of the XXX team. Some are on payroll, some are fee for service, some are even bartering as I share resources with my fellow small business owners." 
Participants 4, 5, and 8 offered that they have enhanced their personal business knowledge just from having engaged in their small business endeavor; But followed by saying it only served to show them how much they still don't know. Participants 4-8 counseled others that having a complement of diverse expertise is key to the success of any small business. And that it is a must for any owner to listen to the advice and ideas, giving thoughtful consideration to any endeavor. Participant 6 offered,

I became more open to listening to others once I realized that I didn't have to know it all nor do it all. And that expertise is not the telling me what to do, rather it is the best thinking of someone more knowledgeable about a particular area than me. But in the end, the final decision is still mine.

Participant 8 finished with "once I let myself off the hook for having to know it all, I was free to make the critical decision my business needed."

\section{Alignment With Literature}

Keating et al. (2013) also concluded that small business owners must recognize when their organization's ability to sustain without his or her capacity requires bringing in external expertise. All participants supported Theme 3; most remarked that they cannot do it all nor know it all, and they just need someone who knows specific specialized areas of the business better than them.

Management education and experience were referred to by Chinomona (2013) as being a component that small business owners must possess when seeking to build a sustainable operation. Participant 2 mentioned continuing education as a tool he used to remain competent in his industry.

Participants 5 and 7 noted tapping into various workshops offered by local small business administration centers and area universities. Participants 2, 5, and 6 noted responses aligning with the research of Teck-Hong and Yong-Kean (2012) when they said that business owners who promoted continuing education throughout their business had a lower risk of failure. Participants 5 and 6 also noted the need to provide additional training and education for key employees.

\section{Theme 4: Ensuring Sound Financial Management}

During the interviews, Participants 4-8 mentioned proper funding or financial management strategies as a key component of building a sustainable business. They each continued that they wish they had been better prepared regarding financial management strategies and encouraged any small business owner to gain additional knowledge first but to also surround themselves with key expertise in all things financial. Participant 5 offered, "Many of my fellow small business owners have gone under because of cash flow issues. They were making money but the inability to manage actual cash flow caused them to go under." Participant 4 observed, "Many startups are grossly underfunded. After tapping friends and relatives, maxing out credit cards, nothing is left to turn that last corner in business. Often it has made the difference between success or failure." Participant 6 shared a need to also "diversify funding sources to minimize any external conditions that may indirectly impact your business but may directly impact the ability to get funding when needed." Finally, Participant 7 said that "finances need to be proactively managed or they will manage you."

Theme 4 seems to be reliant on the three other themes. Participants $4-8$ stated that small business owners' ability to manage the finances is well served by building key relationships with bankers, funding agents, vendors, and employees. They need to tap the resources of various expertise in a cost effective manner, but must also continually enhance their own personal knowledge about finance. 
Doing so will enable them to better utilize the expertise of others while retaining the final decision making role with confidence. Participant 7 furthered, "Otherwise, financial pressures and concerns can turn a passion to an ulcer." So building relationships, enhancing financial knowledge, maintaining the passion are three key strategies in developing a keen financial management system. And according to Participants 4-8, developing a keen financial management system is vital to the sustainability of any small business.

\section{Alignment With Literature}

Previous researchers also revealed capital and financial management effectiveness as a characteristic that small business owners must be proficient in to sustain their business. Proper funding and having financial management procedures can aid in the sustainability of a small business (Kozan \& Akdeniz, 2014; Moeller \& Valentinov, 2012).

Keating et al. (2013) stated that if a business owner does not have specific skills in a particular area, he or she must be able to recognize their lack of competence and be willing to go outside the organization to complete the task. Participants 4 and 6 echoed this finding, acknowledging the need for financial expertise early on in their business development. The same participants both stated that this utilization of external financial sources helped guide them through various stages of their business' life cycles. Furthermore, Participants 1 and 2 both described how they utilized external assistance through vendors and suppliers to strengthen the financial success of their business.

\section{Applications to Professional Practice}

The results of this study provide strategic perspectives for sustaining small businesses beyond 10 years. The findings offer four themes to help potentially build sustainable business models for small businesses. Such information can be perused and can be used by existing small business owners to enhance their understanding of general strategies that support their sustainability efforts. It can also be useful to future small business owners as they develop their business models for achieving and sustaining small business' success. Such results can be helpful in guiding various stakeholders of small business owners, such as business school professors, consultants, and government officials, as they advance supportive services to cultivate successful small businesses in their communities. Overall, such findings can advance the evolution of sustainable business models that meet the needs of small business owners.

\section{Recommendations for Further Research}

Data saturation was achieved after interviewing three participants in this study, but included an additional five participants to further verify and replicate results in a different city. A study based in a different geographical location, other than the southeastern United States, is recommended see if findings are regionally unique.

We also recommend that future researchers study a specific industry of small business owners as opposed to various industries. Also, a longitudinal study conducted over a more extensive period is recommended to account for changes in business stability and variants in industry types. Finally, we recommend conducting a study of small businesses that have greater than 50 employees. 


\section{Conclusion}

The application of the strategies revealed from the study may assist similar small business owners in creating successfully sustainable businesses that operate beyond 10 years. Addressing the four themes-(a) building relationships, (b) finding your passion, (c) enhancing business knowledge, and (d) ensuring financial management-may support the development of sustainable business models. While these findings are expected to be relevant to current and future small business owners, they are equally important to small business support resources like business school professors, business consultants, government officials, and community business leaders. Together, small business owners and their stakeholders may use the findings to advance the evolution of sustainable business models and practices that meet the needs of small business. Advancing this successful evolution of small business' successes in turn may affect communities by employing more people, contributing to local communities through taxes, and offering goods and services at the local level for citizens' convenience.

\section{References}

Anderson, A. R., \& Ullah, F. (2014). The condition of smallness: How what it means to be small deters firms from getting bigger. Management Decision, 52, 326-349. doi:10.1108/MD-102012-0734

Augusto, F. J., Eduardo, C., \& Jorge, C. (2012). Human capital and social capital in entrepreneurs and managers of small and medium enterprises. Journal of Business Economics \& Management, 13, 395-420. doi:10.3846/16111699.2011.620139

Chinomona, R. (2013). Business owner's expertise, employee skills training and business performance: A small business perspective. Journal of Applied Business Research, 29, 18831892. http://dx.doi.org/10.19030/jabr.v29i6.8224

Chrisman, J. J., McMullan, W. E., Ring, J. K., \& Holt, D. T. (2012). Counseling assistance, entrepreneurship education, and new venture performance. Journal of Entrepreneurship and Public Policy, 1, 63-83. doi:10.1108/20452101211208362

Cote, R. G. (2012). Perceived impact of networking relationships on innovation in a life science company: A quantitative study (Doctoral dissertation). Available from ProQuest Digital Dissertations and Theses database. (Order No. 3498730)

Degeorge, J., \& Fayolle, A. (2011). The entrepreneurial process trigger: A modeling attempt in the French context. Journal of Small Business and Enterprise Development, 18, 251-277. doi:10.1108/14626001111127061

de Klerk, S., \& Saayman, M. (2012). Networking as key factor in artpreneurial success. European Business Review, 24, 382-399. doi:10.1108/09555341211254490

Ede, A. N., Bamigboye, G, Olofinnade, O. M., Omole, D. O., Adeyemi, G. A., \& Ben, U. (2016). Impact of reliable built structures in driving sustainable development goals: A look at Nigerian building structures. Presented at the 3rd International Conference on African Development Issues, Ota, Nigeria. Retrieved from http://eprints.covenantuniversity.edu.ng/6717/\#.WfNsTmhSwuU 
Fielden, S. L., \& Hunt, C. M. (2011). Online coaching: An alternative source of social support for female entrepreneurs during venture creation. International Small Business Journal August, 29, 345-359. doi:10.1177/0266242610369881

Jones, O., \& Jayawarna, D. (2010). Resourcing new businesses: Social networks, bootstrapping and firm performance. Venture Capital, 12, 127-152. doi:10.1080/13691061003658886

Keating, A., Geiger, S., \& McLoughlin, D. (2013). Riding the practice waves: Social resourcing practices during new venture development. Entrepreneurship Theory and Practice, 38, 1207 1208. doi:10.1111/etap.12038

Kozan, M. K., \& Akdeniz, L. (2014). Role of strong versus weak networks in small business growth in an emerging economy. Administrative Sciences, 4, 35-50. doi:10.3390/admsci4010035

Labedz, C. S., \& Berry, G. R. (2011). Making sense of small business growth: A right workforce template for growing firms. Journal of Applied Management and Entrepreneurship, 16, 6179.

Lussier, R. N., \& Halabi, C. E. (2010). A three-country comparison of business success versus failure prediction model. Journal of Small Business Management, 48, 360-377. doi:10.1111/j.1540627X.2010.00298.x

Malchow-Moller, N., Schjerning, B., \& Sorensen, A. (2011). Entrepreneurship, job creation and wage growth. Small Business Economics, 36, 15-32. doi:10.1007/s11187-009-9173-y

Moeller, L., \& Valentinov, V. (2012). The commercialization of the nonprofit sector: a general systems theory perspective. Systematic Practice and Research, 25, 365-370. doi:10.1007/s11213-011-9226-4

Navis, C., \& Glynn, M. (2011). Legitimate Distinctiveness and the entrepreneurial identity: Influence on investor judgements of new venture plausibility. Academy of Management Review, 36, 479-499. doi:10.5465/amr.2008.0361

Neumark, D., Wall, B., \& Junfu, Z. (2011). Do small businesses create more jobs? New evidence for the United States from the national establishment time series. Review of Economics \& Statistics, 93, 16-29. doi:10.1162/REST_a_00060

Patel, P. C., Fiet, J. O., \& Sohl, J. E. (2011). Mitigating the limited scalability of bootstrapping through strategic alliances to enhance new venture growth. International Small Business Journal, 29, 421-447. doi:10.1177/0266242610396622

Philip, M. (2011). Factors affecting business success of small \& medium enterprises (SMEs). Asia Pacific Journal of Research in Business Management, 1, 1-15.

Prasad, S., Tata, J., \& Guo, X. (2012). Sustaining small businesses in the United States in times of recession. Journal of Advances in Management Research, 9, 8-28. doi:10.1108/09727981211225626

Schaupp, L. C., \& Bélanger, F. (2014). The value of social media for small businesses. Journal of Information Systems, 28, 187-207. doi:10.2308/isys-50674

Soriano, D. R., \& Castrogiovanni, G. J. (2012). The impact of education, experience and inner circle advisors on SME performance: Insights from a study of public development centers. Small Business Economics, 38, 333-349. doi:10.1007/s11187-010-9278-3 
Sullivan, D. M., \& Marvel, M. R. (2011). Knowledge acquisition, network reliance, and early-stage technology venture outcomes. Journal of Management Studies, 48, 1169-1193. doi:10.1111/j.1467-6486.2010.00998.x

Tasnim, R., Yahya, S., \& Zainuddin, M. N. (2014). "I'm loving it!" What makes the successful entrepreneur affectively committed to entrepreneurial performance? Journal of Applied Management and Entrepreneurship, 19, 27-52.

Teck-Hong, T., \& Yong-Kean, L. (2012). Organizational commitment as a moderator of the effect of training on service performance: An empirical study of small- to medium-sized enterprises in Malaysia. International Journal of Management, 29, 65-76.

Toson, L. R. (2012). Inspiring leadership through networking: Narrative study of women in middle management roles. (Doctoral Dissertation). Available from ProQuest Digital Dissertations and Theses database. (Order Number 3494775)

Tracy, S. J. (2010). Qualitative quality: Eight "Big-Tent" criteria for excellent qualitative research. Sage Journals, 16, 837-851. doi:10.1177/1077800410383121

U.S. Small Business Administration. (2014). Strategic plan and updates. Retrieved from http://www.sba.gov

Viljamaa, A. (2011). Exploring small manufacturing firms' process of accessing external expertise. International Small Business Journal, 29, 472-488. doi:10.1177/0266242610390595

Wang, J., \& Shapira, P. (2012). Partnering with universities: a good choice for nanotechnology startup firms? Small Business Economics, 38, 197-215. doi:10.1007/s11187-009-9248-9

Yallapragada, R. R., \& Bhuiyan, M. (2011). Small business entrepreneurships in the United States. Journal of Applied Business Research, 27, 117-122.

Yin, R. K. (2014). Case study research: Designs and methods (5th ed.). Thousand Oaks, CA: Sage Publications, Inc.

Zahra, S. A., \& Wright, M. (2011). Entrepreneurship's next act. Academy of Management Perspectives, 25, 67-83. doi:10.5465/amp.2010.0149

The International Journal of Applied Management and Technology (IJAMT), sponsored by Walden University's School of Management, is a peer-reviewed, online journal that addresses contemporary national and international issues related to management and technology. The objectives of the IJAMT are to: (a) encourage collaborative and multi-disciplinary examinations of important issues in business and technology management, and (B) engage scholars and scholar-practitioners in a dynamic and important dialogue.

Walden University Publishing: http://www.publishing.waldenu.edu 